\title{
AS GRAMÁTICAS DE LÍNGUA PORTUGUESA DO SÉCULO XVI: QUESTÕES LINGUITICAS, POLÍTICAS E IDENTITÁRIAS
}

\section{NELCI VIEIRA DE LIMA}

Doutora em Língua Portuguesa pela Pontifícia Universidade Católica de São Paulo (PUC-SP),

São Paulo, SP, Brasil.

E-mail: nevieira@gmail.com

\section{Resumo}

Este artigo explana a respeito dos aspectos linguísticos, políticos e identitários imbricados na construção das primeiras gramáticas de Língua Portuguesa, no século XVI, de João de Barros (1496-1570) e Fernão de Oliveira (1507-1581). O quadro teórico que sustenta as análises é o da Historiografia Linguística (KOERNER, 1996, 2014; SWIGGERS, 2009, 2012; AUROUX, 2009). A questão que permeia a pesquisa e nos impele à busca ao entendimento é: em que medida é possível encontrar na leitura das primeiras gramáticas da Língua Portuguesa traços políticos e identitários arraigados aos aspectos linguísticos? De antemão, afirmamos que as primeiras gramáticas de uma língua, conforme processo de gramatização descrito por Auroux (2009), foram feitas com objetivos diversos, ou seja, com vistas ao ensino, seja da língua materna ou do latim, mas também como forma de delinear e marcar a identidade do povo que fala aquela língua. Os aspectos políticos envolvidos na construção de tais gramáticas se devem não só às perspectivas de domínio político e expansão territorial, questões profundamente incutidas ao largo espírito do homem renascentista, mas 
também ao fato das obras gramaticais se constituírem como espaço de institucionalização da língua naquele dado momento histórico, de grande fervor nacionalista e desejo imperial.

\section{Palavras-chave}

Gramatização. Identidade. Política.

\section{INTRODUÇÃO}

Alicerçados no quadro teórico da Historiografia Linguística, nos princípios de Contextualização, Imanência e Adequação (KOERNER, 1996), este artigo traz uma análise do pensamento linguístico dos homens do século XVI, a saber, João de Barros (1496-1570) e Fernão de Oliveira (1507-1581), a respeito de questões linguísticas, políticas e identitárias frente à língua neolatina por eles descrita pela primeira vez, naquele momento histórico. Assim, nossa abordagem segue o parâmetro dado por Swiggers (2009, p. 71), da "dimensão correlativa do programa cognitivo", que segundo o autor, "consiste no estudo das relações entre teorias e da correlação entre ponto de vista em linguística, contexto sociocultural, político e institucional, seguindo o critério do formato combinatório de exposição", ou seja, os pontos de vistas são sempre atrelados às ideias e práticas linguísticas e correlacionados ao seu contexto.

No que tange às questões políticas e identitárias, intencionamos perceber o tratamento dado à língua portuguesa de forma geral, sob um viés político-ideológico, de caráter nacionalista e doutrinário.

Dado o objetivo do trabalho e tendo definido o quadro teórico que o possibilita, passemos à divisão didática do artigo, que compõe-se por três partes, fora essas breves considerações iniciais e as finais: 1. gramática como instrumento político-cultural; 2. o conjunto didático-pedagógico de João de Barros e A Gramática da Linguagem Portuguesa, de Fernão de Oliveira e 3. o tratamento dado à língua portuguesa de forma geral, sob um viés político-ideológico, de caráter nacionalista e doutrinário. 


\title{
GRAMÁTICA COMO INSTRUMENTO POLÍTICO-CULTURAL
}

Ao voltarmos nosso olhar à situação linguística da Europa, no século XVI, nos deparamos com o processo de "gramatização", conforme cita Auroux (2009), movimento a partir do qual as línguas do mundo começaram a ser descritas nos moldes da gramática greco-latina. Entre os fatos que impulsionaram o movimento de descrição das línguas neolatinas, aponta Auroux (2009, p. 50, grifos do autor):

\begin{abstract}
Em um contexto no qual já existe uma tradição linguística, a necessidade de aprendizagem de uma língua Li e uma língua Lj, é potencialmente a primeira causa da gramatização (para qualquer uma das duas). Essa necessidade é capaz de responder ela mesma a vários interesses práticos: i) acesso a uma língua de administração; ii) acesso a um corpus de textos sagrados; iii) acesso a uma língua de cultura; iv) relações comerciais e políticas; v) viagens (expedições militares, explorações); vi) implantação / exportação de uma doutrina religiosa; vii) colonização. (...) A segunda causa da gramatização concerne essencialmente à política de uma língua dada (ela é, pois, suscetível de afetar a língua materna) e pode reduzir a dois interesses: viii) organizar e regular uma língua literária; ix) desenvolver uma política de expansão linguística de uso interno e externo.
\end{abstract}

Interessa-nos frisar, então, esse aspecto político da sistematização da língua, aliado à exportação de uma doutrina religiosa e à colonização. O que coloca o ato de instrumentalizar a língua, por meio da escrita da gramática, como uma ação político-cultural. Dessa forma, construir uma gramática, nesse recorte histórico quinhentista, constituía-se como uma prática sistematizada de intervenção na língua. Corrobora com nossa argumentação o pensamento de Leite (2007, p. 67, grifos do autor), ao afirmar que:

A gramática é um instrumento de cultura, e o trabalho sobre ela não revela somente dados linguísticos. E sobre a língua, não importa apenas a teoria, também os comentários que o gramático registra podem revelar dados importantes sobre a atitude linguística dos usuários de uma línguagrifos do autor.

Dessa forma, partindo desse posicionamento teórico, que considera gramática como elemento cultural e como prática sistematizada de intervenção linguística, realizamos a leitura das gramáticas renascentistas. Num primeiro 
momento, apresentamos as análise do conjunto didático-pedagógico de João de Barros, intitulado Gramática da Língua Portuguesa, cuja publicação data de 1540 e compõe-se das seguintes partes: "Cartinha”, "Gramática” (a qual traz uma versão fac-similada), "Diálogo em louvor da nossa linguagem” e "Diálogo da viciosa vergonha”. Ressaltamos que a obra lida foi preparada por Buescu, com introdução, leitura atualizada e notas.

Ressaltamos também que nosso intento ao realizar as leituras é o de desvelar e entender o pensamento linguístico dos autores e, principalmente, captar seu posicionamento político-ideológico no tratamento da língua, de forma a relacionar tais posturas com os aspectos contextuais que as envolvem.

Passemos, então, à exposição das análises.

\section{O CONJUNTO DIDÁTICO-PEDAGÓGICO DE JOÃO DE BARROS E A GRAMÁTICA DA LINGUAGEM PORTUGUESA, DE FERNÃO DE OLIVEIRA}

A abordagem às obras de João de Barros (1971) e Fernão de Oliveira (1975), neste trabalho, com vistas a desvelar seus posicionamentos político-ideológicos frente à língua, nos intima, constantemente, ao exercício da 'imanência', passo koerniano que consiste na tentativa do historiógrafo em olhar o objeto histórico, despido de seu quadro de formação na Linguística moderna. Lancemo-nos, então, ao desafio.

Em relação à apresentação detalhada das obras, ressaltamos que, como outros pesquisadores já se empenharam em descrevê-las, nos eximimos aqui da responsabilidade dessa tarefa e remetemos nosso leitor diretamente às considerações acerca dos pontos das obras que são de interesse neste percurso. Assim, lembramos apenas que o conjunto didático-pedagógico, de João de Barros (1540 [1971]), é composto por quatro partes: "Cartinha”, "Gramática”, "Diálogo em louvor da nossa linguagem" e "Diálogo da viciosa vergonha", enquanto a gramática de Fernão de Oliveira (1975) é apresentada em apenas um volume, não muito extenso, porém rico em conteúdo analítico. 


\section{O TRATAMENTO DADO À LÍNGUA PORTUGUESA DE FORMA GERAL, SOB UM VIÉS POLÍTICO-IDEOLÓGICO, DE CARÁTER NACIONALISTA E DOUTRINÁRIO}

Neste tópico nos empenhamos em expor, a nosso leitor, a análise que fizemos das obras, por meio da qual buscamos evidenciar, de forma geral, as sequências argumentativas que marcam o posicionamento político dos autores frente à língua portuguesa, no século XVI.

Assim, tomemos, primeiramente, o conjunto didático-pedagógico de João de Barros que, conforme já ressaltamos, compõe-se de quatro obras que, juntas, se complementam e constituem-se como a concretização do objetivo, não só didático-pedagógico, mas também, a nosso ver, político do autor.

A primeira parte, "Cartinha", dedicada às crianças em fase inicial de aprendizagem, traz clara a intenção alfabetizadora e catequizadora de João de Barros (1971, p. 239-240), objetivo que, segundo ele, só poderia ser alcançado por meio do ensino da língua portuguesa: "Quál será, logo, a linguagem que nesta tenra e dilicáda idade de vossa Alteza mais natural e mais obediente vos deve ser, senám a vossa portuguesa, de que vos Deos fez prínçipe e rei em esperança?". Neste outro trecho, questiona o autor: "que linguagem per arte podem máis facilmente aprender senám aquéla que neles obrou salvaçam?”. Assim, exalta sempre a língua portuguesa, afirmando ser esta "mádre e nam madrasta, mádre e nam ama, nóssa e nam alhea".

Não obstante, tendo o nosso homem renascentista manifestado seu primordial interesse em alfabetizar e catequizar os "mininos", comparando a “Cartinha” com o "primeiro leite de sua criaçám” (BARROS, 1971, p. 292), podemos depreender o entendimento, na leitura das entrelinhas, que, por ser um objeto pedagógico e semeador da doutrina cristã, é também um instrumento que veicula o caráter político-ideológico do autor, de cunho doutrinário e nacionalista. Expliquemo-nos: ora, por um lado, se a Igreja Católica foi, durante séculos, detentora absoluta de poderes políticos nas nações que abraçaram seus dogmas, como é o caso de Portugal, João de Barros, ao posicionar-se como sujeito da ação de catequizar, está também abraçando a causa política de colocar pessoas sob o domínio da Igreja.

Por outro lado, podemos afirmar que a ação de ensinar é também um ato político, uma vez que não há prática pedagógica indissociável da prática política, ou seja, o ato pedagógico é também um ato político, de um ser que se 
posiciona politicamente para ensinar algo a alguém. O caráter nacionalista está, a nosso ver, presente no objeto a ser ensinado, no caso, a língua portuguesa, uma vez que o gramático é defensor da necessidade do ensino da língua materna preceder ao ensino do latim, sobre o que afirma Maria Leonor Carvalho Buescu (apud BARROS, 1971, p. XLI):

João de Barros, contudo, aparece já como que envolvido no processo duma alteração pedagógica que levaria, na segunda metade do século, a uma tendência - muito mais moderna, devemos dizer - para fazer preceder o estudo da gramática Latina pelo estudo da gramática nacional.

Em relação ao conteúdo da "Cartinha”, é importante ressaltar que é apresentado em duas partes, sendo a primeira dedicada às letras, sempre acompanhadas de gravuras, e ainda à descrição das famílias silábicas. A segunda parte, de caráter catequizador, traz inúmeras orações, sempre em latim e em português, traz também gravuras de imagens dos apóstolos, e explicações sobre os sacramentos da Igreja, e sobre a missa. Nesse tópico, interessamo-nos apenas pela introdução, na qual são manifestadas as sequências argumentativas, reveladoras do pensamento do autor.

Na sequência, temos a "Gramática da Língua Portuguesa”, parte em que João de Barros (1971) manifesta não só seu pendor pedagógico, mas também seu caráter latinista, uma vez que, toda a composição da gramática é empreendida nos moldes da gramática latina. A esse respeito, afirma Borges Neto (2009, p. 44, grifos do autor):

Para os renascentistas, o latim é considerado uma língua superior às outras (particularmente às línguas vernáculas, que no fundo não são mais do que corruptelas do latim clássico) e, portanto, quanto mais uma língua se parecer com o latim, mais perfeita será considerada. Parte importante dos esforços de valorização das línguas vernáculas, então, será empreendida na demonstração de que as línguas vernáculas têm estrutura semelhante à do latim. Não se poderia esperar, então, que o modelo gramatical adotado fosse outro que não o modelo latino, assim, como não se poderia esperar que a atitude dos gramáticos fosse outra que não a de ver as gramáticas das línguas vernáculas como reflexos das gramáticas do latimgrifos do autor.

Para Buescu (apud BARROS, 1971, p. XLIV-XLV), apesar de Barros considerar "a filiação latina da língua portuguesa e a sua conformidade com ela 
constituírem títulos de nobreza e um dos motivos de louvor da língua portuguesa", o autor também "não deixa de reconhecer a individualidade do português em relação à língua-mãe”. A estudiosa ressalta também que a “preocupação de Barros em individualizar a língua portuguesa por oposição à latina torna-se insistente pela repetição do processo comparativo".

Essa questão da aproximação versus distanciamento do latim, por João de Barros, é também comentada por Leite (2007, p. 232), que afirma ser esse um ponto "paradoxal na obra de João de Barros porque, se, de um lado, quer afirmar a importância do português como língua, de outro, quer vê-la o mais possível 'afiliada' à latina, para mostrar sua eficácia e perfeição”.

Para nós, essa questão, apesar de parecer dúbia, é também de cunho identitário, uma vez que, ao se aproximar do modelo latino, o autor busca não só a autoafirmação perante o modelo clássico de língua, mas, sobretudo, perante a imagem do domínio político outrora exercido pelos latinos. Por outro lado, ao se distanciar, busca a autoafirmação da nação portuguesa, marcada pela individualidade de sua língua perante o próprio latim e em relação às outras línguas europeias que despontavam naquele momento, e que estavam sendo gramatizadas. Para Barros (2001, p. 27), “pode-se dizer que, além do discurso gramatical dominante, já mencionado, entrecruzam-se no discurso da gramática outros discursos também dominantes: o discurso político da monarquia, o discurso ético-religioso da época, o discurso ufanista português”.

Outra característica de João de Barros (1971), expressa em sua gramática e que, para nós, se traduz em uma marca ideológica e nacionalista, é sua posição em relação às questões ortográficas da língua portuguesa. No entanto, é possível afirmar que há indícios de que o gramático tivesse um projeto ortográfico para o português quinhentista, uma vez que se em tudo havia o modelo da gramática latina a ser seguido, isso não ocorria na ortografia, algo totalmente novo. Cada língua neolatina teria que se empenhar para construir sua própria ortografia, fosse ela de cunho etnográfico ou fonético.

Afora isso, na descrição linguística apresentada na gramática, o autor faz uso de uma linguagem concisa, conforme Buescu revela (apud BARROS, 1971), distanciando-se do modelo especulativo da gramática medieval, o que é condizente com o caráter didático que visava imprimir à obra. No decorrer dos capítulos, não há mais manifestações argumentativas de caráter político-ideológico, no entanto, ressaltamos que, para nós, o ato de instrumentalizar a língua por meio da escrita de uma gramática se constitui, por si só, em um ato político. 
Marcas mais profundas da postura política adotada por João de Barros frente à língua podem ser encontradas no "Diálogo em louvor da nossa linguagem”, em que o autor forja um diálogo com o filho, com vistas a conclamar o louvor e a defesa da língua portuguesa. No princípio do diálogo, uma questão que parece incomodá-lo é sobre qual teria sido a primeira língua do mundo, explicação que, pela postura manifestadamente cristã, busca na Bíblia, mais especificamente com a passagem de Pentecostes:

Donde pódes entender que a linguagem primeira de Adám [h]oje está no mundo: em ésta naçám dez vocábulos, nest'outra vinte, e assi está repartida, que todos â tem em vóz, mas nam em um só sinificado. E ainda se póde crer que éstas vózes, com antiguidade, já dévem ser corrompidas, como vemos em muitos vocábulos gregos, hebraicos e latinos, que foram as três linguagens a que podemos chamar princesas do mundo, porque ésta autoridade lhe [s] deu o títolo da cruz onde foram postas. Éstas, porque perderam já a vez do uso, e tem somente a párte da escritura, leixá-lâs-emos por outras três que fázem ao propósito da nóssa, as quáes, ao presente, todalas outras precedem, por tomárem, déstas primeiras, pártes de seus vocábulos, prinçipàlmente da latina, que foi derradeira que teve a monarquia, cujos filhos nós somos. (BARROS, 1971, p. 396).

Como podemos notar no trecho acima, João de Barros não deixa de ressaltar a filiação à língua latina e tem consciência do fenômeno da mudança linguística, na perspectiva diacrônica, exaltando as línguas grega, hebraica e latina, chamando-as de "princesas".

Logo à frente, outra passagem traz o questionamento do filho sobre qual seria a língua de maior elegância, ao que responde imediatamente o pai:

Â que se máis conforma com a latina, assi em vocábulos, como na ortografia. $\mathrm{E}$ nésta parte, muita vantagem tem a italiana e espanhól à françesa, e, déstas duas, â que se escréve como se fála, e que menos consoantes léva perdidas. $E$, nesta ortografia, a espanhól vence a italiana; e máis, tem entre se os genoeses, que nam é térra da tramontana nem transalpina (como eles dizem), mas $\square a$ parte da frol da Itália, os quáes, de bárbora, nam podem escrever sua linguagem, e ô escrévem é em toscano, ou em latim corruto. (BARROS, 1971, p. 397, grifos do autor).

A partir da resposta do pai ao filho, notamos que, se a elegância de uma língua está em sua conformidade com o latim, então, por que não perseguir esse ideal para a língua portuguesa? E sendo a italiana a que mais leva vanta- 
gem nesta parte, por que não se basear nela para o planejamento de um projeto ortográfico para a língua portuguesa? (cf. BUESCU apud BARROS (1971).

Outro ponto que pode ser destacado, ainda no trecho supracitado, é a abordagem às línguas bárbaras que, para João de Barros, não poderiam ser escritas ou são escritas em toscano ou latim corrupto, o que seria motivo de desprestígio para uma língua. Dessa forma, descrever e instrumentalizar uma língua, fixando para ela um sistema gráfico seria, então, motivo de grande prestígio, postura adequada de quem se preocupa em louvar e defender a língua portuguesa, e para isso, numa atitude prática, escreve sua gramática.

Este outro trecho também se faz revelador de uma postura que visa enaltecer e defender a língua, e esbarra na complexa relação de rivalidade tida entre o português e o espanhol nos quinhentos:

F <ILHO> - Pois muitos dizem que a língua espanhól é desfalecida de vocábulos, e que, quanta vantáge tem a italiana à castelhana, tanto exçede ésta a portuguesa, e que em seu respeito se póde chamár elegante.

$P<A l>$ - Çerto é que a língua castelhana muito melhor é que o vansconço de Biscáia e o çeçear cigano de Sevilha, as quáes nam se podem escrever. Mas, quem [h] ouvér de julgár éstas linguagens, [h] á de saber d’ambas tanto, que entenda os defeitos e perfeições de cada $\mathrm{Da}$. Que se póde desejár na língua portuguesa que éla [não] tenha? Conformidade com a latina? Nestes vérsos, feitos em louvor da nossa pátria, se póde ver quanta tem, porque assi sam portugueses, que ôs entende o português, e tam latinos, que ôs nam estranhará quam souber a língua latima. (BARROS, 1971, p. 397, grifos do autor).

Ao citar os versos sobre os quais se refere, o filho pergunta: "Paréce que vái éssa linguágem um pouco retorçida e fóra do comum uso que falamos?" (BARROS, 1971, p. 398), e o pai argumenta alegando sobre a existência de variação linguística na fala dos poetas. Fica claro, no entanto, com esse trecho que a língua portuguesa - considerada inferior às outras, principalmente à castelhana - é defendida, pelo gramático, com muito afinco, argumentando que cada uma tem seus defeitos e perfeições e que as línguas não devem ser julgadas. A esse respeito afirma Buescu (apud BARROS, 1971, p. XXXI):

A posição de João de Barros no que respeita a este ponto, parece que se insere na polémica mais ou menos latente durante os séculos XVI e XVII entre os decididos apologistas da língua nacional e os que reconheciam a superioridade da castelhana como língua de maior circulação, expressividade e riqueza. Con- 
tra esses, opõe-se vigorosamente João de Barros como qualidades essenciais, riqueza vocabular, conformidade com o Latim, gravidade e majestade, sonoridade agradável, capacidade de exprimir ideias abstractas, possibilidade de formação de novos vocábulos.

Buescu (apud BARROS, 1971, p. XXXI) aponta também uma posição paradoxal de Barros sobre essa questão da riqueza vocabular do português, porque, segundo ela, ele próprio reconhece em outro momento ser o "português vocabularmente mais pobre que os idiomas" grego e latino.

A partir das análises realizadas, podemos afirmar que é no "Diálogo em louvor da nossa linguagem" que as manifestações argumentativas, reveladoras do posicionamento político-ideológico de João de Barros no tratamento da língua, são mais latentes. Neste outro trecho do diálogo com o filho, podemos observar, mais uma vez, o enaltecimento da língua:

P<Ál> - Aí começarás tu de sentir o louvor da nóssa linguágem que, sendo nossa, â entenderá o latino porque é sua. Ésta prerrogativa tem sobre todalas linguágens presentes: majestáde pera cousas gráves, ũa eficáçia baroil que representa grandes feitos. E o sinal onde isto máis claro ve, é na música, que, naturalmente, àçerca de cada naçám, ségue o modo da fala: linguágem gráve, / música gráve e sentida.

F<ILHO> - Daí viria lógo o provérbio que dizem: Espanhóes chóram, Italianos uivam, Franceses cantam.

$\mathrm{P}<A ́$ l $>$ - Bem adecáste o provérbio. E, ainda que nam seja pera a linguágem, verdadeiramente assi ô pódes ter na música, porque a prolaçãm e ár que temos da linguágem, diferente das outras nações, temos o módo de cantar, cá mui estranha compostura é a francesa e italiana à espanhól, e as guinádas e deminuiçam que fázem ao cantar, fázem na prolaçám e açento da fála. E, pera um francês formár um seu próprio ditongo, fáz nos beiços esgares que póde amedrontar mininos, cousa de que um naturál orador fóge. E, por nam cair neste perigo, rodea setenta vocábulos. Çérto assi a françesa, como a italiana, máis parecem fála pera molhéres, que gráve pera homens, em tanto, que, se Catám fora vivo, me paréçe se pejára de â pronunçiár.

Nésta gravidade, como já disse, a portuguesa léva a todas, e tem em si ũa pureza e sequidám pera cousas báixas [...] (BARROS, 1971, p. 398-399, grifos do autor).

É notável, por meio dos exemplos, a preocupação de João de Barros (1971) em adjetivar a língua portuguesa a fim não só de enaltecê-la, mas, também, de elevá-la ao posto de melhor e mais elegante entre as línguas europeias. 
Com essa atitude, ele tenta distinguir sua língua das demais, e o curioso é que aponta o defeito das outras, chegando a dizer, por exemplo, que, para "um francês formár um seu próprio ditongo, fáz nos beiços esgares que póde amedrontar mininos, cousa de que um naturál orador foge" (BARROS, 1971, p. 398), ou então que o francês e o italiano parecem língua de mulheres.

Rico em exemplos que denotam a postura político-ideológica do gramático em relação à língua, o diálogo com o filho segue recheado de colocações em defesa da língua materna. Quanto a isso, convém lembrar que o que tentamos comprovar aqui não é se o português tinha ou não o status de melhor língua entre as neolatinas, naquele século, mas que, independentemente de ser ou não uma língua pobre, rural ou rica e de ciência, homens de espírito patriótico e humanista como João de Barros se esforçaram para promovê-la perante as outras nações.

Neste outro trecho, destacamos os verbos indicadores das ações intrínsecas à língua, para o gramático: “declarar”, “mover”, “deleitar”, “exortar”. Vejam que o autor cita Gil Vicente (1465-1537), numa postura nacionalista de exaltar seu conterrâneo, buscando o exemplo de um clássico escritor e argumenta que mesmo para Aristóteles, se tivesse a língua portuguesa como natural, encontraria nela uma riqueza vocabular que o permitiria escrever todos os seus tratados.

A linguágem portuguesa, que tenha ésta gravidade, nam perde a força pera declarár, mover, deleitár e exortar a párte a que se enclina, seja em quál género de escritura. E Gil Viçente, cómico que â máis tratou em composturas que alg destes reinos, nunca se atreveu a introduzir um Çentúrio português, porque, como ô nam consente a naçãm, assi ô nam sófre a linguágem. Çérto, a quem nam falecer matéria e engenho pera demonstrar sua tençám, em nossa linguágem nam faleçerám vocábulos, porque de crer é que, se Aristóteles fora nósso naturál, nam fora búscar linguágem emprestada para escrever na filosofia e em todolas outras matérias de que tratou. (BARROS, 1971, p. 400, grifos do autor).

Consideramos importante o fato de que João de Barros, a partir do conhecimento que as vivências em seu tempo o permitiram, tinha plena consciência da mudança e evolução das línguas. Assim, como o renascentista não deixa de admirar o clássico, mas com o espírito aberto às mudanças linguísticas e sociais, busca valorizar o que é seu, nem que para isso seja preciso efetuar uma série de comparações entre os portugueses e os latinos, entre a língua de antes e a de então. No recorte que fazemos a seguir, o diálogo é sobre a derivação de 
vocábulos do latim, a qual o autor reconhece e não se opõe, manifestando sua posição, reveladora do apreço pelo clássico:

\begin{abstract}
$\mathrm{P}<A ́ l>-A$ mi, muito me contentam os termos que se confórmam com o latim, dádo que sejam antigos, cá destes nos devemos muito prézar, quando nam achármos serem tam correctos, que este labéo lhe [s] fáça perder sua autoridáde. Nam sòmente ôs que achamos per escrituras antigas, mas muitos que se usam Antre Douro e Minho, conservador da semente portuguesa, os quáes alguns indoutos desprezam, por nam saberem a raiz donde náçem. (BARROS, 1971, p. 402, grifos do autor).
\end{abstract}

A consciência de João de Barros a respeito da variação diacrônica da língua é visível também no trecho abaixo, no qual ressalta o poder do tempo em modificar as coisas, entre elas, a própria língua. "O tempo, pois este fáz as cousas tam naturáes, como a própria natureza. Este nos deu a elegância latina; este nos trouxe a barbária do godos; este nos deu $x a$ e cha dos mouriscos, e este nos póde fazer ricos e póbres de vocábulos, segundo o uso e prática que tivérmos das cousas" (BARROS, 1971, p. 403).

A seguir, Barros (1971) desvela o pensamento do gramático/pedagogo sobre a importância de o ensino de português preceder ao ensino do latim. Como argumento, ele usa o próprio exemplo da atitude dos gregos e latinos frente suas línguas, atitude que o gramático incita para que seja copiada pelos portugueses, ou seja, para que se deem a aprender primeiro a sua língua e depois a dos outros:

[...] Este é o módo que tiveram todolos Gregos e Latinos: tomáram por fundamento saber primeiro o seu que o alheo. Quéro dizer, que Túlio, Çésar, Lívio e todolos outros a que chamamos fonte da eloquênçia, nunca aprenderam língua latina como a grega, poque éra naturál linguágem, tam comum ao povo romano, como vemos que a nóssa é ao povo de Lisboa, mas soubéram a gramática dela. (BARROS, 1971, p. 403, grifos do autor).

Outro aspecto que o gramático enaltece e inveja nos gregos e latinos, diz respeito à imposição linguística aos povos dominados, conforme a citação abaixo:

Estes e outros tam gráves e doutos barões, em cuja mam e arbítrio estáva o estádo e regimento do mundo, assi [h] ouvéram este exercício por glorioso, que na força de suas conquistas e ármas, ali ô exercitavam. E àçerca deles, máis se 
estimáva a vitória que a sua língua tinha, em ser reçibida de todalas bárbaras nações, que de âs someter ao jugo do seu império. E neste cuidádo foram tam solíçitos, que, andando antre os pártos e outros tam bárbaros póvos, não consentiam que falássem senám a sua língua latina, por demonstrar que o império que tinham sobre todalas outras nações. (BARROS, 1971, p. 404, grifos do autor).

É forte a presença de sua atitude nacionalista e imperialista também em relação aos feitos gloriosos dos portugueses que, assim como os latinos, iam aos poucos conquistando novas terras e agregando novas colônias à metrópole, para as quais a língua portuguesa seria o seu legado, assim como o latim havia sido outrora para eles.

Exemplo temos em todalas monarquias, cá, se perderam com a variedáde do tempo e fortuna das cousas humanas, peró leixou a língua latina este sinál de seu império, que durará eternalmente. As ármas e padrões portugueses, postos em África e em Ásia, e em tantas mil ilhas fóra da repartiçám das três pártes da térra, materiáes sam, e póde-âs o tempo gástar, peró nam gastará doutrina, costumes, linguágem, que os Portugueses néstas térras leixárem. (BARROS, 1971, p. 405).

Certo para ele é que melhor seria deixar sua língua nas terras por onde passassem os portugueses, do que a de lá trazer a língua alheia, o que se comprova no primeiro trecho do diálogo, abaixo reproduzido:

F<lLHO> - Nem sei, lógo, quál será o português de tam errado juízo, pois é çérto que mais póde durar um bom costume e vocábulo que um padrám, porque se nam préza máis leixár na India este nome, mercadoria, que trazer de lá beniága, cá é sinál de ser vençedor e nam vencido.

P<Ál> - Çérto é que nam [h]á i glória que se póssa comparar a quando os mininos etíopas, persianos, indos, d’além do Gange, em suas próprias térras, na força de seus templos e pagodes, onde nunca se ouviu o nome romano, per ésta nóssa árte aprenderem $s$ nóssa linguágem, com que póssam ser doutrinádos em os preçeitos da nóssa fé, que néla vam escritos. (BARROS, 1971, p. 405, grifos do autor).

Para finalizar a análise do "Diálogo em louvor da língua portuguesa", tomemos esse segundo trecho da citação acima, no qual João de Barros (1971) vislumbra a glória que será para outros povos ao tomar conhecimento da língua portuguesa, para que "póssam ser doutrinádos em os preçeitos da nóssa fé, que néla vam escritos” (BARROS, 1971, p. 405). Como vemos, o autor do 
conjunto didático-pedagógico reconhece ser a língua instrumento para a imposição política do povo português sobre as outras nações e não se esquece da missão de levar também a fé cristã aos povos dominados.

A seguinte afirmação de Casagrande (2005, p. 138, grifos do autor) vem corroborar com as análises expostas até aqui: "No Diálogo em louvor da nossa linguagem, podemos perceber a presença de uma política linguística que se instaura, num primeiro momento, na medida em que o diálogo entre pai e filho discute a imposição da língua latina pelo Império Romano, quando de sua dominação".

À medida que João de Barros vê as ações do Império Romano como exemplos para o povo português, no sentido de seguirem os mesmos passos em relação ao domínio geográfico, político, cultural e linguístico, vamos percebendo suas intenções nacionalistas e imperialistas.

A leitura atenta à última parte da obra de João de Barros, "Diálogo da viciosa vergonha”, nos revela uma parte do caráter pedagógico do autor, para quem a educação deveria abranger também os domínios da moral, no entanto sendo a obra despida de manifestações político-ideológicas em relação à língua, não nos ateremos a ela.

Desvelados, então, os pensamentos de João de Barros, que nos permitiram delinear sua postura frente à língua, passemos agora à exposição da análise da obra de Fernão de Oliveira (1536 [1975]).

Se comparada à obra de João de Barros (1971), considerando-se o conjunto didático-pedagógico em suas quatro partes, a obra de Fernão de Oliveira (1975) torna-se pequena e condensada, o que, de maneira alguma a destitui de sua importância para os estudos historiográficos da língua portuguesa. Muito pelo contrário, a leitura atenta à obra revela a grandiosidade do espírito humanista de seu autor, manifestada por seu interesse em descrever e instrumentalizar a nova língua, registrando de forma pioneira seus padrões fonéticos.

A exaltação à língua e ao povo português é registrada logo na introdução da obra, quando Fernão de Oliveira (1975, p. 37) afirma tratar-se de "língua de tão nobre gente e terra como é Portugal”. Como mencionado anteriormente, já na introdução o autor define o padrão linguístico que visa a descrever, porém sem deixar de se atentar, no decorrer da obra, às variações regionais da língua. Assim, procura estabelecer um padrão normativo do que considera como ideal linguístico: 
[...] não presumo ensinar aos que mais sabem, mas notarei o seu bom costume para que outros muito aprendam e saibam quanto prima é a natureza dos nossos homens porque ela por sua vontade busca e tem de seu a perfeição da arte que outras nações adquirem com muito trabalho [...] (OLIVEIRA, 1975, p. 38, grifos do autor).

A postura, marcadamente político-ideológica, é manifestada em todos os capítulos da gramática. Assim, em meio às descrições linguísticas, Oliveira (1975) vai tecendo seus comentários, argumentando sempre a favor do povo português, de forma a exaltar a maestria de sua língua. A nosso ver, essa maneira de escrever, intercalando descrição e argumentação, parece ter como explicação o fato da obra se distanciar do padrão estrutural de apresentação da gramática latina, ao qual recorreu João de Barros (1971). Não é à toa que o Fernão de Oliveira (1975, p. 38) nomeia seu empreendimento como anotação. Esse caráter de anotação traz, então, mais liberdade para o autor se manifestar, do que teria tido se tivesse optado por desenvolver uma gramática nos padrões tradicionais.

Isto posto, continuemos a demonstrar, por meio de exemplos, a postura de nosso gramático renascentista perante a língua. No trecho abaixo, chamamos a atenção para a adjetivação elencada para a língua: antiga, ensinada, próspera, bem conservada:

[...] nós falamos com grande repouso, como homens assentados. E não somente em cada voz por si, mas também no ajuntamento, e no som da linguagem pode haver primor ou falta entre nós. Não somente nestas, mas em muitas outras coisas ter a nossa língua vantagem, por que ela é antiga, ensinada, próspera e bem conversada e também exercitada em bons tratos e ofícios. (OLIVEIRA, 1975, p. 39, grifos do autor).

Podemos notar a aproximação de duas áreas nas quais o povo português buscava obter êxito no século XVI: na guerra e na língua. O que pode ser constado pela aproximação dos dois campos semânticos, representados pelas palavras ‘armas' e 'letras'. Essa dualidade será percebida em muitas outras passagens da obra, nas quais o gramático relaciona o poderio alcançado pelo Império Romano, em outros tempos, pelo domínio das armas e imposição do latim, com o imperialismo ultramarino português, que despontava em sua época. Nas palavras de Oliveira (1975, p. 41, grifos do autor): "E assim desta feição, já também este nome de Portugal é antigo e agora, com a virtude da gente, muito enobrecido e com muitos bons tratos e conversações, assim em armas como em letras engrandecido". 
Faz-se claro que Fernão de Oliveira, assim como João de Barros, nutria a intenção de contribuir, por meio da instrumentalização da língua portuguesa, para o estabelecimento de uma política linguística que levasse a língua lusitana a outras nações por eles dominadas. Com isso, buscavam glorificar seu povo e eternizar sua língua: "esses estudos fazem mais durar a glória da terra em que florescem" (OLIVEIRA, 1975, p. 42, grifos do autor). No trecho que vem logo em seguida a esse, é revelada a inspiração para tal intento: "Porque Grécia e Roma só por isto ainda vivem, porque quando senhoreavam o Mundo mandaram a todas as gentes a eles sujeitas aprender suas línguas (OLIVEIRA, 1975, p. 42). Assim, segue o discurso político-ideológico de Fernão de Oliveira (1975), repetindo muitas vezes, no decorrer da obra, a necessidade de eternizar a glória de seu povo por meio da imposição de sua língua.

[...] apliquemos nosso trabalho a nossa língua e gente e ficará com maior eternidade a memória dele e não trabalhemos em língua estrangeira, mas apuremos tanto a nossa com boas doutrinas, que a possamos ensinar a muitas outras gentes e sempre seremos delas louvados e amados porque a semelhança é causa do amor e mais em as línguas. (OLIVEIRA, 1975, p. 45).

Ainda em tempo, abrimos aqui um espaço para uma pequena ressalva, mas de grande importância para o entendimento de nosso percurso historiográfico. Assim, quando nos ocupamos, neste artigo, da tarefa de evidenciar as marcas da política de imposição linguística intencionada pelos gramáticos renascentistas, não pretendemos com isso fazer significar que, de fato, os portugueses tenham tido êxito em seu empreendimento, muito pelo contrário, não o tiveram, num primeiro momento, assim como afirma Leite (2007, p. 188-189): "Portugal repetiu a prática romana sobre seus conquistados, embora sem a mesma força e competência político-administrativa. No Brasil, por exemplo, o português não foi a língua dos conquistados até o século XVIII, 1770, ano do alvará pombalino, que obrigava o ensino da língua portuguesa”.

Não obstante, mesmo a questão da imposição linguística tendo ficado, a princípio, somente no campo das intenções, não tendo nossos autores quinhentistas alcançado, em vida, a propagação de sua língua pelo mundo, fato indubitável é que a língua portuguesa ganhou forças e se expandiu para terras alheias. Dessa forma, prossigamos com a exposição de nossa análise, embora pelos exemplos já citados, já esteja comprovada a posição política-ideológica do autor para o tratamento da língua, que deixa claro seu caráter 
nacionalista e doutrinário. Antes, é importante notar apenas um fato, para o qual chamou nossa atenção Casagrande (2005, p. 123), que "em [Fernão de] Oliveira a questão da identidade nacional se faz muito mais latente do que a questão religiosa, embora tenha sido ele um dominicano". Diferente de João de Barros, Fernão de Oliveira não se prende às questões da fé e moral cristã.

Outro aspecto que diferencia os dois gramáticos é o tratamento dado ao latim. Embora reconhecendo sempre a origem latina da língua portuguesa, sua intenção parece ser muito mais de marcar as diferenças entre as línguas, no intuito de valorizar a sua língua materna, do que apontar as semelhanças. Concordamos com Borges Neto (2009, p. 48), ao afirmar que a argumentação em Fernão de Oliveira caminha na "direção de uma igualdade entre a atitude dos portugueses em relação a sua língua e a atitude dos latinos em relação ao latim”. Os trechos abaixo são manifestações tanto desse sentimento patriótico, que envolve, ao mesmo tempo, repulsa e admiração aos latinos, quanto do desejo imperialista do povo português, de assim como aqueles fizeram em outras épocas, senhorear o mundo:

E desta feição nos obrigaram a que ainda agora trabalhemos em aprender e apurar o seu, esquecendo-nos do nosso. Não façamos assim, mas tornemos sobre nós agora que é tempo e somos senhores, porque melhor é que ensinemos a Guiné que sejamos ensinados de Roma, ainda que ela tivera toda a valia e preço [...] Mas nós somos tão grandes bugios dos Latinos que tomamos suas coisas sem muito sentir delas quanto nos são necessárias. E por nossa vontade damos nossas avantagens aos Latinos e Gregos, que tampouco sabem às vezes o que há mister, como os que entre nós pouco sentem [...] Perguntarei: então, que nos fica a nós? Ou se temos de nosso alguma coisa? E os nossos homens, pois são mais antigos que os Latinos, porque também não ensinariam? Porque seriam em tudo e sempre ensinados? (OLIVEIRA, 1975, p. 42-84, grifos do autor).

Feitas as explanações sobre a postura de João de Barros e Fernão de Oliveira frente à língua, atendemos ao que nos propomos com o estabelecimento do critério analítico, que visava a refletir sobre os aspectos políticos e identitários imbricados na construção das primeiras gramáticas de língua portuguesa, o que revela o caráter político e doutrinário das obras. 


\section{CONSIDERAÇÕES FINAIS}

As análises das obras de João de Barros (1540 [1971]) e Fernão de Oliveira (1536 [1975]), apresentadas neste artigo possibilitaram-nos perceber o pensamento linguístico manifestado pelos gramáticos, no qual a língua é tratada como instrumento político, imprescindível para o exercício do domínio cultural, político e econômico.

As primeiras gramáticas de nossa língua foram construídas dentro de um movimento maior, conforme descrito e nomeado por Auroux (2009) como Gramatização. Assim, se gramatizar uma língua é também instrumentalizá-la, descrevendo seus padrões por meio da escrita de sua gramática, por sua vez, escrever a primeira gramática de uma língua constitui-se como um ato político, capaz de institucionalizar essa língua, delimitando assim, a identidade da nação que a fala.

Os gramáticos, ao defenderem sua língua, manifestaram seu pensamento linguístico, de cunho político, nacionalista e doutrinário.

\section{Century XVI grammars of the Portuguese language: linguistic, political and identity issues}

\section{Abstract}

This study outlines the linguistic, politics and identity aspects, integrated on the building of the first grammars of Portuguese Language, in XVI century, of João de Barros and Fernão de Oliveira. The theoretical framework that supports these analyses is the one from Linguistic Historiography (KOERNER, 1996, 2014; SWIGGERS, 2009, 2012; AUROUX, 2009). The matter that permeates the research and drive us forward to search the understanding is: in what measure is it possible to find, in the reading of the first grammars of Portuguese Language, politics and identity traits embedded in linguistic aspects? Beforehand, we assume that the first grammars of a language, according to the Grammaticalization process described by Auroux (2009), were done with several objectives, that is, so as to teaching, either of the mother language or of Latin, and also as a mode to shape and mark the identity of the people that speaks that language. The political aspects involved in the building of such grammars are due not only to political domain prospects and territorial expansion, issues deeply embedded into the spirit of the Renaissance man, but also to the fact that grammatical books constitute themselves as an institutionalization space of the language in that historical moment, of great nationalist fervor and imperialist desire.

60 


\section{Keywords}

Linguistic Historiography. Grammaticalization. Identity. Politics.

\section{REFERÊNCIAS}

AUROUX, S. A revolução tecnológica da gramatização. Tradução: Eni Puccinelli Orlandi. Campinas: UNICAMP, 2009.

BARROS, J. de. Gramática da Língua Portuguesa: Cartinha, Gramática, Diálogo em Louvor da nossa Linguagem e Diálogo da Viciosa Vergonha. Introdução, leitura atualizada e notas Maria Leonor Carvalhão Buescu. Rio de Janeiro: Imprensa Nacional - Casa da Moeda, 1971.

BARROS, D. L. P. de. O discurso da norma na gramática de João de Barros. Revista Alfa, São Paulo, v. 45, p. 11-32, 2001.

BORGES NETO, J. A teoria da linguagem de Fernão de Oliveira. In: ABAURRE, M. B.; PFEIFFER, C.; AVELAR, J. (Orgs.). Fernão de Oliveira: um gramático na história. Campinas: Pontes Editores, 2009, p. 43-51.

CASAGRANDE, N. dos S. A implantação da Língua Portuguesa no Brasil do século XVI: um percurso historiográfico. São Paulo: EDUC, 2005.

LEITE, M. Q. O nascimento da gramática portuguesa: uso e norma. São Paulo: Paulistana; Humanitas, 2007.KOERNER, E. F. K. Questões de persistem em historiografia linguística. Revista da ANPOLL, n. 2, p. 47-70, 1996.

KOERNER, E. F. K. Quatro décadas de historiografia linguística: estudos selecionados. Publito, Estúdio de Artes Gráficas, Braga, 2014.

OLIVEIRA, F. de. A Gramática da Linguagem Portuguesa. Lisboa, 1536. Introdução, leitura atualizada e notas por Maria Leonor Carvalhão Buescu. Rio de Janeiro: Imprensa Nacional - Casa da Moeda, 1975.

SWIGGERS, P. La historiografia de lalingüística: apuntes y reflexiones. Revista argentina de historiografia linguística, v. I, n. 1, p. 67-76, 2009.

SWIGGERS, P. Linguistic historiography: object, methodology, modelization. Revista Todas as Letras: Revista de Língua e Literatura - Universidade Presbiteriana Mackenzie, v. 14, n. 1, São Paulo, 2012. 